\title{
Financial Flexibility - A Synthesis of Literature Review
}

\author{
Md Rashidul Islam (Corresponding author) \\ Doctoral Student, School of Accounting, Dongbei University of Finance and Economics \\ 217, Jianshan Street, Liaoning Province, Dalian, China \\ Assistant Professor, East West University (On study leave), Dhaka-1212 \\ E-mail: rmislam2002@yahoo.com
}

\begin{abstract}
Man Wang
Professor, School of Accounting, Dongbei University of Finance and Economics/Internal Control Research Centre in China

217, Jianshan Street, Liaoning Province, Dalian, China
\end{abstract}

Leo Vashkor Dewri

Senior Lecturer, Department of Business Administration

East West University, Dhaka, Bangladesh

Received: May 24, 2018

doi:10.5296/ijafr.v9i1.13195
Accepted: February 1, 2019 Published: February 13, 2019

URL: https://doi.org/10.5296/ijafr.v9i1.13195

\begin{abstract}
Financial flexibility has engrossed considerable interest of researcher over the last three decades. It is considered as most critical element of capital structure decision. The objectives of this research are to synthesize the existing literature on financial flexibility and find the literature gap. First, we show the relationship between theories and financial flexibility from existing literature and discuss the relationship between cash holding, leverage, payout policy and impact on firm performance during and after financial crisis. Second, we discuss how off balance sheet instruments impact on leverage and financial flexibility. We also discuss the relationship between corporate governance, corporate social responsibility and financial flexibility. We evidence from existing literature that financial flexibility has positive relationship on investment and firm performance during and after financial crisis. In addition
\end{abstract}


to that we conclude that the off balance sheet instrument financing is increasing abnormally, and it has effect on debt policy and financial flexibility that yet to be studied verified. We further document from the current literature that corporate social responsibility and corporate governance may also widen financial flexibility in the US market but no significant researcher addressed these issues in the developed markets. While using Altman's Z-Score for measuring financial flexibility it is unable to accommodate off balance sheet items therefore market demands for adjusted Z-Score.

Keywords: Financial flexibility, Cash holding, Off balance sheet financing

\section{Introduction}

Financial executives comprehend financial flexibility is one of the most critical elements of capital structure decisions (Mitoo and Bancel, 2009). Financial Flexibility engrossed considerable interest of the researcher over the last three decades particularly in 1990's (Liu, 2017). The idea came from the optimal capital structure proposition of Modigliani and Miller (1963) and revealed that firms do not use borrowed capital as much as anticipated considering the income tax shield due to saving debt capacity in order to keep flexibility to respond future capital necessity. This created a flexible theory in the field of finance and is now called financial flexibility. It expresses the firm's ability to re-act financing needs as means of accessing external funds at economic rate and restructure the capital structure (Gamba and Triantis, 2008).

It is argued that firms having financial flexibility have greater access to financial markets to raise the funds for combating unexpected financial situation and investment opportunities (De Angelo and De Angelo, 2007). These firms' always attempt to hold better cash position to grab investment opportunity. However, the mechanism works for being financially flexible to carefully consider cash dividend policy, leverage, capital structure, liquidity and investment (Gamba and Triantis, 2008). Financially flexible firms paying cash dividend have lower investment reduction than firm's without flexibility (Daniel et al. 2008).Consequently, cash dividend decision is crucial for firm's growth as it decreases firms net worth increasing investors' personal net worth. It may also curb firm's expansion strategy and firms should carefully choice dividend policy (Dewri et. al. 2015) for being financially flexible. Similarly, financially flexible firm's hold low level of debt that gives them strong strength to combat risk and chances of default (Bates et.al. 2008).

The importance of being financially flexible comes from the notion that it is the one of the best tool which is used as intangible assets of the firm (Kuo et. al. 2006) to combat firm's economic problem. It is argued that about $86 \%$ of financially constrained firm's postponed or cancelled their planned investment during financial crisis(2007-2008) and sold their assets to fund their firm's operating activities (Campello et. al. 2010). In contrast, financially flexible firms outperform non-financially flexible firms and value of the firm has positive association with financial flexibility during the financial crisis (Tong and Wei, 2008). However, firms with high financial flexibility underperform in the down market and there is no association between excess flexibility and future profitability (Simutin, 2010). 
During the last three decades world economies faced several economic meltdown and academicians considered financial flexibilities and its significance pre and post crisis and crisis period (Arslan et. al. 2014). Nonetheless, no researcher compiled all conducted researches in this area. Consequently, the purpose of this survey is to compile the research existing research works, synthesizes different theories and explores the scope of new research.

This research attempts to explore: the existing theories that promote financial flexibility, determinants of financial flexibility, the relationship between off balance sheet instruments (i.e leases, special entities, guarantees) and financial flexibility, the association of corporate governance, corporate social responsibilities with financial flexibility, and, how to measure financial flexibility.

In this study, we review the literatures that have been conducted in relation to financial flexibility. We discuss: the existing theories that promote financial flexibility, determinants of financial flexibility, the relationship between off balance sheet instruments (i.e leases, special entities, guarantees) and financial flexibility, the association of corporate governance, corporate social responsibilities with financial flexibility, and, how to measure financial flexibility. To the best our knowledge, no literature review has systematically and comprehensively assessed the different issues associated with financial flexibility. We therefore make several contributions to the existing literature. First, we provide a systematic assessment of theoretical considerations and help to identify how important the financial flexibility is and how can it be obtained. Second, we offer a narrative based assessment of empirical results with relation to financial flexibility. Finally, we provide an overview of the current state of research and provide academics with directions that may guide future research. The rest of the paper is organized as follows; the next section presents the theoretical framework of financial flexibility. Section 3 discusses the determinant of financial flexibility, while section 4 presents off balance sheet financing and financial flexibility. Section 5 presents the relationship between financial flexibility and firm performance. Section 6 represents corporate governance, cash holding and financial flexibility. Section 7 discusses corporate social responsibility and financial flexibility while section 8 presents techniques of measuring financial flexibility. Finally, the conclusion presents some orientation for future research

\section{Theoretical Framework and Financial Flexibility}

Cash holdings, internal funds and spare leverage capacity have been used as proxy of financial flexibility in the contemporary capital structure literature (Arslan et. al., 2014; Ma \& Jin, 2016). Leverage and cash used to be closely associated as leverage provides more access to the cash and the significance of liquidity to access in financial flexibility leads to the Keynes liquidity preference theory (1973) and inventory management theories of Baumol (1952) as key theoretical foundation of financial flexibility framework.

Cash holding has transaction cost savings and precautionary motive benefits (Keynes, 1973) as raising funds through issuing initial public offering, right share offering or bond issuing requires permission form the regulators and involves underwriter and other costs. If the firms 


\section{MlMacrothink}

International Journal of Accounting and Financial Reporting

ISSN 2162-3082

2019, Vol. 9, No. 1

have excess cash then managers can use them for funding continuing operations and extended investment opportunities even if others sources of finance unavailable which also studied by Myers and Majluf (1984). Keynes (1973) evidenced that for an agreed net debt there is an optimal volume of cash where cash is not merely net debt.

Few more early research of liquidity is Baumol (1952) and Miller and Orr (1966). Baumol (1952) proposes a model of weighted benefits of cash holding and suggests cash is an asset and needs to be managed like other tangible assets as converting other tangible assets into cash involves high costs. These two theories suggest liquidity and spare debt capacity is a critical driver of firm's financial flexibility

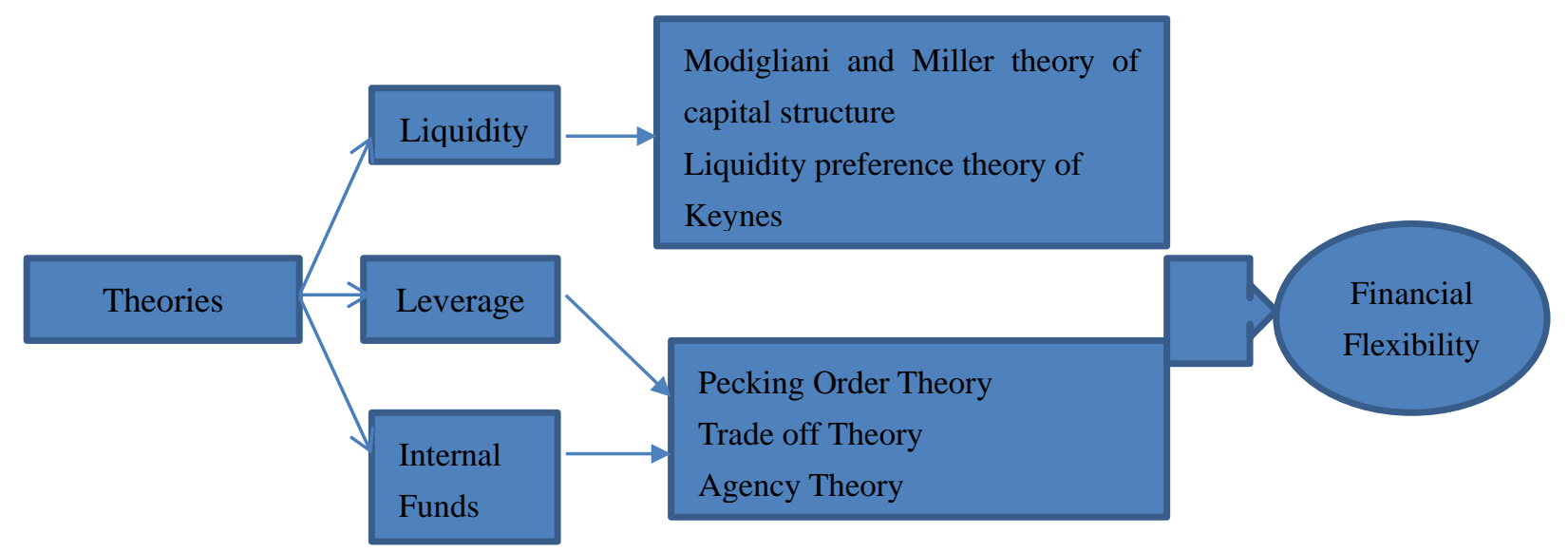

Source: Authors

Modigliani and Miller (1958) suggests that in the perfect capital market, the absence of: transaction costs, taxation, different borrowing costs, bankruptcy costs and symmetry of market information, the firm value is not dependent on capital structure decision. Instead, they argued that firm value is dependent on earning power and by the risk of underlying assets. This proposition implied that firms can generate required funds when necessary and requisite for improving and sustaining financial flexibility will drop. However, the underlying assumptions of this theory is no longer valid in the real world practices and it's uses in the imperfect capital market is questioning. Moreover, financing decision is relevant and the essence for financial flexibility is demanding when cash flows and investing opportunities are uncertain (Byoun,2011). While funding opportunities are uncertain for profitable projects and firm wants to maximize its value financial flexibility become extremely important as the term financial flexibility is associated with the ability of availing and reformation the financing strategies without plummeting appreciated investment opportunities (Byoun, 2011).

According to trade off theory of capital structure companies should select funding source based on balancing cost and benefit. More precisely, the theory proposes that firm select the level of debt balancing tax advantages of debt with augmented cost of potential bankruptcy (Kraus and Litzenberger, 1973; Myers and Majluf, 1984).Similarly, pecking order theory (Myers and Majluf, 1984) of capital structure suggests financing source based on risk involved and proposed that firm should choose internal source (retained earnings) followed 
by borrowed funds and equity issues as last resort. Seemingly, these theories proposes different types of funding sources and demonstrate the situations where firm can choose debt or equity as financing source. However, those theories did not consider the market conditions and financing opportunities and market timing hypothesis has been developed and it suggests that whether firms should finance their investment with debt or equity based on market condition (Powers and Tsyplakov, 2008). These make financial flexibility a more significant area of study to face the financial needs and resist in the organization critical financing time.

\section{Determinants of Financial Flexibility}

Leverage seems to be one of the most important determinants of financial flexibility. It is argued that financial flexibility can be obtained by adopting low leverage policy and suggesting that preserving low leverage ratio can generate the capacity of future borrowing power and create room for enhance of leverage ratio (Goldstein et. al., 2001; Byoun, 2011). Conversely, financial flexibility can also be obtained through holding excess cash (Opler et al., 1999; Almeida et. al., 2003; Harford et. al., 2005; Riddiek and Whited, 2009). They argues that holding ample of cash gives opportunity to exploit chances of good investment enhancing firms' growth opportunity and protect firms from adverse situation (Riddiek and Whited, 2009). However, recent literature suggest that adopting the above two policies (Low leverage \& High cash holdings) can lead to better financial flexibly and avoid distress of financial shake and default (Bates et al.2009; Byuon, 2011).

Corporate payout policy is also a one of the significant determinant of financial flexibility. It is argued that firms' employ dividend policy to preserve financial flexibility. Distribution of cash dividend is a strategic tool to exploit internal funds when facing downturn of operating performance and potential investment opportunity (DeAngelo and DeAngelo, 2007; Oded 2008). In contrast, holding excess cash may lead to cash abuses and agency benefits. As a result, firms have tendency to distribute dividends or repay debt. Nevertheless, dividend policy acts as a tradeoff between preserving financial flexibility and abolition of agency costs (Liu, 2017).

Augmenting financial flexibility to face the funding needs of valuable investment opportunities few more ways were prescribed by extant literature. Using commercial paper (Kahl et. al., 2008) could be one of the best way of enhancing financial flexibility who does not want to face costs regarding registration with stock exchanges .Similarly, bank borrowing over bond financing is favorable way for firms with high demand for flexibility(Freixas,2000). Additionally, firms can raise their financial flexibility through retiring debt by using callable bonds(Powers and Tsyplakov,2008).However, issuing or retiring debt depends on firms condition of financial surplus or deficit. Additionally, firms can enhance financial flexibility by augmenting their retention limit (Eldomiaty and Azim, 2008). Firms can preserve more of their net income when the cost of equity funding is comparatively low. 


\section{Off Balance Sheet Financing and Financial Flexibility}

One of the primary functions of financial managers when facing long term financing decision is how present financing decision might impact on future financing options. Financial flexibility is an increasingly concerned issue by financial managers when making debt policy decision as they want to protect credit firm's credit rating to preserve unused debt capacity to finance future investment opportunities. It is thus no surprise that financial managers consider off balance sheet financing tools to meet their capital funding needs.

It is increasingly important for firms to remain flexible and to be able to adapt quickly to a changing environment. This means that the old, physical asset intensive model may not work as well as it did in the past. Firms need to raise capital to purchase long term physical assets that may be hard to sell in a timely manner. Raising capital costly because debt financing increases the leverage ratio and equity financing can dilute shareholder value. However, some financing tools do don't have to be classified as either debt or equity, and can thus be kept off a firms balance sheet, thereby preserving leverage ratio.
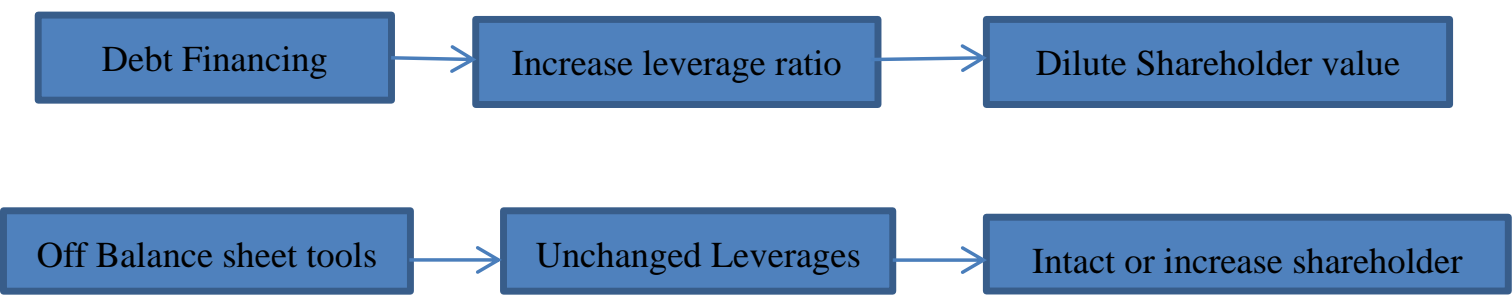

Source: Authors

Off balance sheet financing has been attractive to many firms especially when the addition of a large amount of new financing would break their debt covenants. However, firms should be fully aware of both the positive and negative consequences of using these instruments. Although they have positive effect when use to improve leverage ratio and financial flexibility, they can also lead to legal consequences if used to artificially manipulate financial reports as was the case of Enron. Enron created off balance sheet entities known as SPEs, whose financial statements did not have to be consolidated with Enorn's own statements. Unprofitable assets were then transferred to these entities to hide losses and make the company look financially healthy.

After several accounting scandals in the early 2000, both Securities and Exchange Commission (USA) and Financial Accounting Standard Boards (FASB) increases disclosure requirements for off balance sheet financing instruments and consequently Sarbanes Oxley Act of 2002 (SOX) has been pronounced (Mills \& Newberry, 2005).

Consequently, leases plays an important role as off balance sheet item as a substitute of long term debt (Eisfeldt and Rampini, 2009).In the US the average Compustat firm had lease intensive ratio about $40 \%$ per year. In another word, US firms had present and future rent commitment about 16.6\% of their total assets during 1980-2011 (Devos \& Rahman, 2014; Beatty et. al. 2010) demonstrates that leasing amounts about one third of new equipment in the balance sheet. Similarly, Graham et. al. (1998) evidenced that the ration of 43\%, 6\%, and 
$52 \%$ is operating leases, capital leases and debts to fixed claims. The purposes of operating leases may be to lower the conventional way of reporting debt. However, it is shocking that off balance sheet items has been fundamentally ignored in the theoretical and empirical literature.

Considering leases either capital or operating may in turn affect the total amount of debt and the calculation of leverage ratio, cost of debts, and cost of equity. As a result, firms with high level of debt would prefer to have a capital lease and may prefer to have an operating lease instead.

\section{Financial Flexibility and Firm Performance}

Generally, firms with significant financial flexibility have solid cash flows, strong balance sheets and access to low-cost debts. It is yet to empirically discover whether financial flexible firm lead to strong financial performance in the normal time. Additionally, it is also unanswered whether firm performance varies with the firm characteristics. However, it is argued that during financial crisis financially flexible firms can approach better investment opportunity and perform better than financially inflexible firms (Arslan et. al. 2014).

Multinational companies and local company's performance based on financial flexibility may differ as international firms have to face foreign government regulation, policies, changes of environment and culture (Miller, 1993). Nevertheless, financial flexibility plays significant and positive effects on multinational companies' performance during the financial crisis and handles external shocks with not significant organization structural change (Kuo et. al., 2006)

Firms hold cash for different motives: transaction, precautionary and speculative. Cash and cash equivalents supposed to be the best liquid assets and it does not merely generate earnings either investing or spending for firm operation. Moreover, holding excess cash could enhance the opportunity costs and Jensen and Meckling (1976) propose in agency theory that there is an opposite relationship between cash holding and firm value. However, holding cash at desired level is critical to how financiers observe and evaluate the firm (Kao, 2012).

According to Mahrt-Smith (2007) cash holding and firm value depends on corporate governance and documents that if cash in position is to finance operating activities and offer a buffer an external financing costs then holding cash is a good choice. Conversely, when the corporate governance is poor holding cash may be disadvantageous to the cash value. However, corporate governance features like small percentage of external directors in board and large board size may lead potential embezzlement and responsible for negative relation between cash holding and firm value (Lee and Lee, 2009).

Information asymmetry plays important role to decide holding cash and firm performance. High asymmetry of information lead to low cash holding and vice versa (Drobetz et al, 2010). Pecking-order theory and the transaction costs theory also suggest that there is a positive association between firm value and cash holdings. 


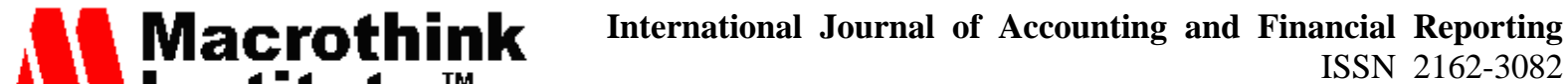 2019, Vol. 9, No. 1}

\section{Corporate Governance, Cash Holdings and Financial Flexibility}

Cash holding used to be very important for firm operation and investment decision as it is observed that by the end of 1998 the biggest companies over the world holds cash and cash equivalents almost $9 \%$ of assets book value and more than $9 \%$ of equity market value. To address this issue Dittmar et. al., (2003) worked on 11,000 firms from 45 different countries and conclude that corporate governance is a significant factors for cash holding. More specifically, in the countries where a strong shareholders right prevails hold less cash. In contrast, countries whose investors are not well protected hold up to double of their counterpart. This is due to poor protection of shareholders leads to some factors less important such as investment opportunities and asymmetric information for cash holding as these countries cannot push managers to eject additional cash balances.

Cash holding also depends on firm size as Opler et al. (1999) evidence that small firms hold more cash when they have opportunities of higher investment and Research and Development Expenditures. Similarly, firms holds more cash when they have acquisition options and these companies are tend to overpay for acquisition and performance at post bid acquisition becomes poor than other bidders(Hartfod,1999) indicating managers intention to build up high cash and involved agency costs. This is because poor corporate governance and weak investor protection (Dittmar et. al. 2003). Additionally, weak corporate governance suggests poor stockholders rights and provide higher discretion of managers that leads to higher cash holding and provide financial flexibility. On the other hand, strong corporate governance forces managers to take rational decision restrain their discretion and hoard cash for good investment opportunities

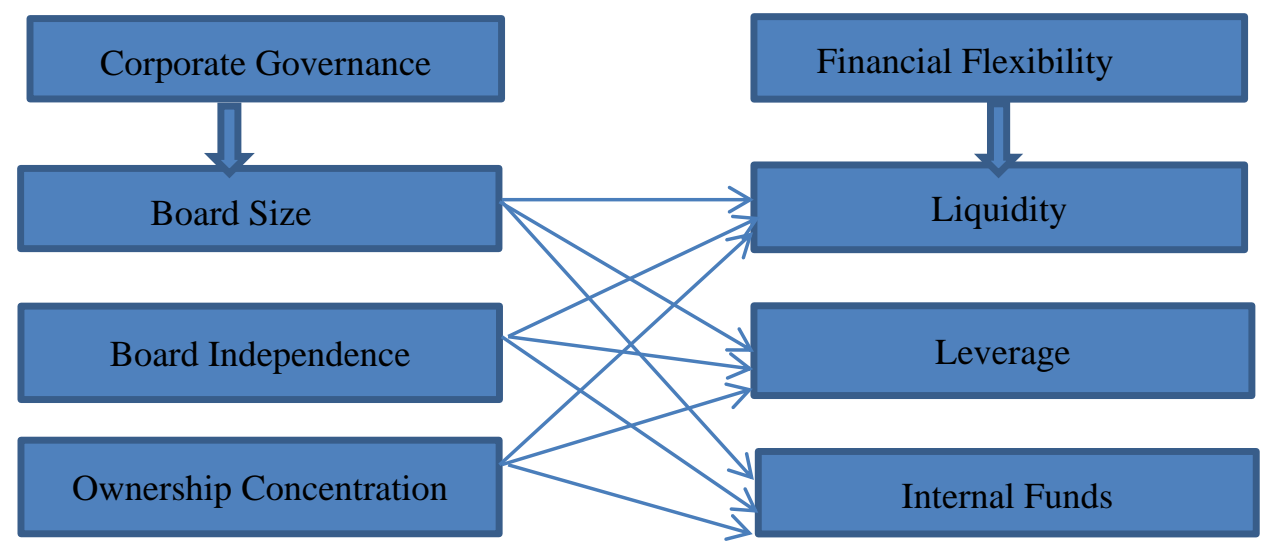

Source: Adapted from Estwick (2016)

Estwick (2016) tests the relationship among corporate governance and financial flexibility and propose hypothesis that board size have positive relationship with firms liquidity and negative relationship with leverage and internal funds. Similarly, board dependence has positive relationship with firm's liquidity and negative relationship with firms leverage and internal funds. Additionally, Ownership concentration has positive association with liquidity but negative relationship with firms leverage and internal funds. He evidenced that high ownership concentration Caribbean firms are linked with the low liquidity but associated with excessive unutilized debt capacity. Additionally, greater board independence has positive 


\section{Ml Macrothink}

International Journal of Accounting and Financial Reporting

ISSN 2162-3082

2019, Vol. 9, No. 1

relation with firms' liquidity indicating weak corporate governance increase agency costs (Jensen, 1986).

\section{Corporate Social Responsibility and Financial Flexibility}

Initially (1990) corporate social responsibility was regarded as strategy that aims to meet the expectation of stakeholders at the cost of stockholders and considered as CSR firms are linked with pessimistic recommendations (Ioannou and Serafeim 2015). However, they argued that currently CSR is considered as risk mitigation strategy and firms with high CSR are attracted by analyst for potential field of investment. Interestingly, firms with high CSR attract more analysts and reduce forecast errors. Dhaliwal et al. (2011) reveals that high CSR US firms disclose more information about their financial and extra financial activities than their counterparts. This is due to the intention to reflect a positive image about firms' image toward their investors and stakeholders and reduce information asymmetry between firms', shareholders and stakeholders (Dhaliwal et al. 2012). Consequently, analyst imposes more impotence on CSR practices due its large impact on firm performance. Similarly, Hong and Kacperczyk (2009) evidenced that weak company can with low CSR information can attract less analyst and found difficulty to finance through issuing equity and satisfy them with little equity issue. These raise questions do weak companies found difficulty to raise fund through debt financing? And, firms' with higher CSR practices get advantages to raise fund through equity issuance and debt issuance. El Ghoul et al. (2011) reveals that in US market firms with high CSR can raise equity finance with low cost and have a tendency to raise funds every two years after good CSR disclosure (Dhaliwal et al. 2011). However, the same questions in the non US market are yet to be tested and answered.

Environmental practices can have effect on cost of capital as environmental risk management can reduce firms' financial distress and enhances quality of debt save form bankruptcy (Sharfman and Fernando, 2008). They also further evidenced that better environment risk management provide lower cost of equity and weighted average cost of capital. In contrast, inadequate environmental risk management is associated with higher cost of debt and equity capital in the US Market. Moreover, environment concerned firms are affected by their credit rating and pay premium for debt and equity financing.

\section{Measurement of Financial Flexibility}

In the recent literature Arslan et al. (2014) financial flexibility is a proxy of firms leverage and cash holdings. They suggest that firms with high cash holding and low leverage are flexible firms as these firms as greater ability to raise external funds. Conversely, firms with high leverage and low cash position indicate less flexible firms. Consistent with this approach Ma\&Jin (2016) measures financial flexibility considered firms liquidity, leverage and internal funds. Previous literature suggests index methods. Proponents of these methods tend to use single index or multiple indexes for measuring financial flexibility. Single index is the index of either leverage Billet, King, and Mauer 2007; Denis and McKeon 2009; or cash holdings (Byoun 2008; Marchica and Mura 2010; Arslan et al. 2012; Hoberg et al. 2014). On the other hand, Multi-index is the combination of number of index to calculate level of financial flexibility (Doidge et. al.2014). However, Altman's $Z$ Score $\left(Z=1.2 X_{1}+1.4 X_{2}+3.3 X_{3}+\right.$ 
$0.6 \mathrm{X}_{4}$ ) also becomes most popular way of measuring financial flexibility (Bancel and Mittoo, 2011). This $Z$ score is composed of ratios of cash and cash equivalent to total assets, EBIT to total assets, retained earnings to total assets Market to book value to total assets and sales divided by total assets. The Z-Score 2.675 is considered green and safe zone for the firm's-Scores more than 2.67 is financially flexible firms. On the other hand, Z-Score 1.81 is considered cut off point and below this point firms are considered inflexible and could cause bankruptcy. However-Score between 1.81 to 2.675 is considered uncertain zone but could be safe for bankruptcy for the next 2 years (James, 2016).

\section{Conclusion}

In this study, we present extensive literature reviews that have evidenced financing decision with firms' financial flexibility. We show that: investigation related to financial flexibility such as different theories that triggers financial flexibility, cash holding or leverage position or more importantly financial constraint as determinant of financial flexibility, the relationship between financial flexibility and firm performance during and after financial crisis, the impact of off balance sheet items and corporate social responsibility on debt policy and financial flexibility and how the relative term financial flexibility can be measured.

Despite the rich literature that has addressed increasing number of subjects related to financial flexibility, there are still many questions that have not received an adequate amount of attention. First, an interesting avenue of research could be the examination of financial flexibility and investment of financial institution. Indeed, direct studies on financial flexibility, investment and performance is rare in banks and other financial studies not only in US but also the rest of the world(Mathew,T.et.al,2004;Kim, et.al.1998)This seems to be very important as banks financial flexibility plays pivotal role to combat recession and economic growth. Second, cash holding, leverage position, financial constraints are proxies as financial flexibility and tested in developed countries like UK, US and Canada etc. However, the business environment, nature of business and business culture across the world may vary and affect the financial flexibility where developing countries has received very few attention and demands for testing financial flexibility and performance. This is due to the literature that suggests financial flexibility is more important in developing countries than developed countries owing to information asymmetry. Finally, Off balance sheet financing instruments are becoming popular mode of financing in the real business world specially developed worlds as these items don't have to be classified as either debt or equity, and can thus be kept off a firms balance sheet, thereby preserves leverage ratio. However, off balance sheet items like leases, special entities, letter of credit and guarantees could have increase the financial flexibility threating future performance but no direct study found in this area.

\section{References}

Arslan, Ö., Florackis, C., \& Ozkan, A. (2014). Financial flexibility, corporate investment and performance: Evidence from financial crises. Review of Quantitative Finance and Accounting, 42(2), 211-50.

Bancel, F., \& Mittoo, U. R. (2011). Financial flexibility and the impact of the global financial crisis: Evidence from France. International Journal of Managerial Finance, 7(2), 179-216. 


\section{Macrothink}

International Journal of Accounting and Financial Reporting

ISSN 2162-3082

2019, Vol. 9, No. 1

Bates, T. W., Kahle, K. M., \& Stulz, R. M. (2008). Why do US firms hold so much more cash than they used to?. J. Finance, 64, 1985-2021

Beatty, A., Liao, S., \& Weber, J. (2010). Financial reporting quality, private information, monitoring, and the lease-versus-buy decision. Account, Rev., 85, 1215-1238.

Billett, M. T., \& Garfinkel, J. A. (2004, October) Financial Flexibility and the Cost of External Finance for U.S. Bank Holding Companies. Journal of Money, Credit and Banking, $36(5), 827-852$.

Byoun, S. (2008). How and when do firms adjust their capital structures toward targets?. Journal of Finance, 63(6), 3069-3096

Campello, M., Graham, J. R., \& Harvey, C. R. (2010). The real effects of financial constraints: evidence from a financial crisis. J. Financ Econ., 97, 470-487

Claessens, S., \& Laeven, L. (2003). Financial Development, Property Rights, and Growth. The Journal of Finance, 58(6), 2401-36.

Daniel, N. D., Denis, D. J., \& Naveen, L. (2010). Sources of financial flexibility: Evidence from cash flow shortfalls. Working paper, Philadelphia, PA, Drexel University.

DeAngelo, H., \& DeAngelo, L. (2007). Capital structure, payout policy, and financial flexibility. Working Paper, Marshall School of Business.

Devos, E., \& Rahman, S. (2014). Location and lease intensity. Journal of Corporate Finance, 29(2014), 20-36.

Dewri, L. V., Islam, M. R., \& Arifuzzaman, S. M. (2015). Behavioral Analysis of Investors' Attitude towards Dividend Declaration in Developing Country-A Case of Bangladesh. International Journal of Business and Management, 10(11).

Drobetz, W., \& Wanzenried, G. (2006). What determines the speed of adjustment to the target capital structure?. Applied Financial Economics, 16, 941-958

Eisfeldt, A., \& Rampini, A. (2009). Leasing, ability to repossess, and debt capacity. Rev. Financ. Stud., 22, 1621-1657.

Estwick, T. (2016). Principal-Principal Agency and Financial Flexibility in Transition Economies. Journal of Business Inquiry, 15(1).

Gamba, A., \& Triantis, A. (2008). The value of financial flexibility. Journal of Finance, 63(5), 2263-96.

Graham, J., Lemmon, M., \& Schallheim, J. (1998). Debt, leases, taxes, and the endogeneity of corporate tax status. J. Finance, 53, 131-162.

Harford, J. (2008). Corporate governance and firm cash holdings in the US. Journal of Financial Economics, 87(3), 535-555.

James, M. (2016). Financial Flexibility and the Impact of the 2007/2008 Global Financial Crisis: Evidence from African Firms. Research Journal of Finance and Accounting, 7(8). 


\section{Mll Macrothink}

International Journal of Accounting and Financial Reporting

ISSN 2162-3082

2019, Vol. 9, No. 1

Jensen, M., \& Meckling, W. (1976). The theory of the Firm: Managerial Behaviour, Agency Costs, and Ownership Structure. Journal of Financial Economics, 3(4), 305-360.

Kao, S. W. (2012). Research note: Cash holding and firm value: the case of Taiwan's tourism industry. Tourism Economics, 18(4), 897-902.

Kim, C. S., Mauer, D., \& Sherman, A. (1998). The Determinants of Corporate Liquidity: Theory and Evidence. Journal of Financial and Quantitative Analysis, 33, 335-359.

Kuo, H. C., Li, Y., Wang, L. H., \& Ding, C. Y. (2006). Flexibility and Performance of MNEs: Evidence from Taiwan. International Journal of Business, 11(4).

Lee, K.W., \& Lee, C. F. (2009). Cash holdings, corporate governance structure and firm valuation. Review of Pacific Basin Financial Markets and Policies, 12(3), 475-508.

Liu, Z. (2017, May). Financial Flexibility and Financial Policy. Educational Research International, 6(2).

Ma, C., \& Jin, Y. (2016). What Drives the Relationship Between Financial Flexibility and Firm Performance: Investment Scale or Investment Efficiency? Evidence from China. Emerging Markets Finance \& Trade, 52, 2043-2055.

Mills, L. F., \& Newberry, K. J. (2005, May). Firms' Off-Balance Sheet and Hybrid Debt Financing :Evidence from Their Book-Tax Reporting Differences. Journal of Accounting Research, 43(2).

Mittoo, U. R., \& Bancel, F. (2009). Why do European firms go public?. European Financial Management, 15(4), 844-884.

Myers, S. C., \& Majluf, N. S. (1984). Corporate financing and investment decisions when firms have information that investors do not have. Journal of Financial Economics, 13, 187-221.

Opler, T., Pinkowitz, R., Stulz, R., \& Williamson, R. (1999). The determinants and implications of corporate cash holdings. Journal of Financial Economics, 52, 3-46.

Simutin, M. (2010). Excess cash and stock returns. Financial Management, 9(3), 1197-1222.

Tong, H., \& Wei, S. J. (2008). Real effects of the subprime mortgage crisis: is it a demand or a finance shock?. Working Paper 14205, National Bureau of Economic Research.

\section{Copyright Disclaimer}

Copyright for this article is retained by the author(s), with first publication rights granted to the journal.

This is an open-access article distributed under the terms and conditions of the Creative Commons Attribution license (http://creativecommons.org/licenses/by/4.0/) 